\title{
MENINGKATKAN KEMAMPUAN PRA KEAKSARAAN ANAK USIA DINI KELOMPOK B MELALUI METODE BERNYANYI DI TK KARTIKA XIX-I
}

\author{
Yulianti $^{1}$, Nita Sumini ${ }^{2}$ \\ ${ }^{1}$ TK Kartika XIX-I, ${ }^{2}$ KB Misykatul Anwar \\ ${ }^{1}$ antiyuli1907@yahoo.co.id, ${ }^{2}$ nitasumini@yahoo.com
}

\begin{abstract}
Singing is an exciting activity and can encompass anxiety and provide relaxation as well as for children. Through the chanting of learning activities will be more fun. To that end, the research team wanted to know about which method can improve children's speaking ability. The aims of this research are: 1) To know the early preemployee literacy early ability. 2) the mention of the singing process. 3) Knowing the process of performing the singing method. 4) To know the results of the implementation of the method of singing.

The method used is Studisis Class (PTK). This research was conducted in one of Kindergarten located in Sarijadi Urban Village, Bandung. The results obtained data on 1) Effective language learning process to develop pre-literacy skills in children's times. 2) Methods of explosion on the use of literacy children. 3) Factors that support and inhibit the ability of pre-literacy early childhood menu process of singing methods.

The recommendations of this study include: 1) For schools, the need for the provision of facilities used to support the pre-literacy skills of children in the early morning. 2) For Educators to know the methods used in building pre-literacy skills in times of children. 3) For the Trustees Agency, as a reference to the method of developing early childhood literacy skills. From the results of this study in the census used is a method that can be used to improve the ability of early pre-literacy.
\end{abstract}

Keywords: singing, pre-literacy

\begin{abstract}
Abstrak
Menyanyi adalah suatu kegiatan yang menarik serta dapat mengatasi rasa cemas dan memberikan relaksasisertaketenanganbagi anak. Melalui nyanyian kegiatan pembelajaran akan terasa lebih menyenangkan. Untuk itu team peneliti berusaha mengetahui sejauh mana metode menyanyi dapat meningkatkan kemampuan bicara anak. Adapun penelitian ini bertujuan: 1) Untuk mengetahui kemampuan awal pra keaksaraan anak usia dini. 2) mengetahui perencanaan metode bernyanyi. 3) Mengetahui proses pelaksanaan metode nyanyian. 4) Untuk mengetahui hasil pelaksanaan metode bernyanyi. Metode yang digunakan adalah Penelitian Tindakan Kelas (PTK). Penelitian ini dilakukan di salah satu Taman Kanak-Kanak yang berada di Kelurahan Sarijadi Kotamadya Bandung. Hasil penelitian diperoleh data mengenai 1) Proses pembelajaran bahasa yang efektif untuk mengembangkan kemampuan pra keaksaraan anak usia dini. 2) Dampak metode bernyanyi terhadap kemampuan pra keaksaraan anak. 3) Faktor-faktor yang mendukung dan menghambat kemampuan pra keaksaraan anak usia dini melalui metode bernyanyi. Rekomendasi penelitian ini diantaranya : 1) Bagi sekolah, perlunya penyediaan sarana prasarana yang digunakan untuk menunjang kemampuan pra keaksaraan anak usia dini. 2) Bagi Pendidik untuk
\end{abstract}




\section{JURNAL CERIA}

ISSN : 2614-6347 (Print) 2614-4107 (Online)

Vol.1 1 No.2 1 Maret 2018

mengetahui penggunaan metode bernyanyi dalam mengembangkan kemampuan pra keaksaraan anak usia dini. 3) Bagi Instansi Pembina,sebagai referensi tentang metode bernyanyi dalam mengembangkan kemampuan pra keaksaraan anak usia dini. Dari hasil Penelitian Tindakan kelas ini dalam disimpulkan bahwa bernyanyi adalah suatu metode yang bisa digunakan untuk meningkatkan kemampuan pra keaksaraan anak usia dini.

Kata kunci : bernyanyi, pra keaksaraan

\section{PENDAHULUAN}

Berdirinyalembaga PAUD yang saatinimenjadisalahsatuprioritasdaripengembanga npendidikansebelumanakmemasukijenjangpendid ikansekolahdasardimana program pembelajaran yang

dikembangkannyamencakupenamaspekperkemba ngan yang mengacupadapermendikbud 137 dan146 tahun 2014.

Anakusiadiniadalahsosokindividu yang sedangmenjalanisuatu proses perkembangandenganpesatdansangat fundamental bagikehidupanselanjutnya (Santoso, 2007: 2.9). Kehidupananakmemilikiduniadankarakteristiksen diri yang jauhberbedadari orang dewasa.Anakselaluaktif, dinamis, antusias, dan rasa ingintahu yang sangatbesarterhadapapa yang dilihat, didengardandirasa, seolaholahtakberhentidalmproseseedukasi.

Padaanak-anak

yang

kitadidiksaatinilahtujuanpembangunanmasadepan bangsadan

dapatdiwujudkanmelaluistiumulus

Negara

diberikanolehlembaga PAUD

yang

nantinyamenjadigenerasipenerus.

Kesadaranakanartipentingnyapenerus yang berkualitasmengharuskankitaseriusmembekaliana kdenganpendidikan yang tepat agar dirinyamenjadimanusiaseutuhnyadanmenjadigene rasi yang lebihhebatdanbermanfaatdarigenerasisebelumnya.

Karakter dan sifat anak yang bervariatif sering ditemui disekolah, seperti anak yang pemalu dan takut untuk mengungkapkan bahasa dan berbicara menjadi tantangan untuk mencari cara dan upaya supaya anak dapat mengungkapkan bahasa dengan kosa kata yang bagus dan benar serta mampu berkomunikasi dengan lingkungan sosialnya baik dilingkungan rumah, sekolah dan lingkungan bermainnya.

Honig, dalamMasitohdkk. (2005:11.3) menyatakanbahwabernyanyimemilikibanyakmanf aatuntukpraktikpendidikananakdanpengembanga npribadisecaraluaskarena:

bernyanyibersifatmenyenangkan, bernyanyidapatdipakaiuntukmengatasikecemasan, 3) bernyanyimerupakan media untukmengekspresikanperasaan, bernyanyidapatmembantumembangun rasa percayadiri,

bernyanyidapatmembantudayaingat, bernyanyidapatmengembangkan rasa humor, 7) bernyanyidapatmembantupengembanganketeram pilanberpikirdankemampuan motoric anak, dan 8) bernyanyidapatmeningkatkankeeratandalamsebua hkelompok.

Denganbernyanyipotensibelahanotakkanananakda patdioptimalkan, sehinggapesan - pesan yang kitaberikanakanlebih lama tersimpan di memorianak.

Anakakanmulaimengungkapkanperasaannyadank einginannyaberbicaradalamlingkungansosialnya.

Adakalanyakitamenemui sifat anak yang pemalu dan susah bergaul di lingkungan masyarakat.Apabila anaktersebut ditanya, anakakan merasa ketakutan dan malu.Biasanya rasa ituakanmunculjikaanakbertemudengan orang baru. Hal tersebut merupakan masalah yang harus dihadapi oleh orang tua dan pendidik, untuk menjadikan anak yang mandiri dan berjiwa sosial tinggi.Atas dasar inilah, peneliti berkeinginan untuk melakukan penelitian dengan judul "Meningkatkan kemampuan prakeaksaraan Anak Usia Dini melalui metode bernyanyi pada kelompok B Di TK Kartika XIX-I". 


\section{JURNAL CERIA}

ISSN : 2614-6347 (Print) 2614-4107 (Online)

Vol.1 1 No.2 1 Maret 2018

\section{METODE PENELITIAN}

Penelitian tindakan kelas dilaksanakan selama 6 bulan, dari 2 Oktober 2016 sampai dengan 6 Mei 2017. Dengan subyek penelitiannya anak didik sebanyak 17 orang, Metode pengumpulan data yang digunakan adalah observasi dengan instrumen berupa daftar cek, dokumentasi dan kepustakaan. Setelah pengetesan tahap awal dilaksanakan dapat diketahui kemampuan kreativitas awal anak, kemudian dilanjutkan dengan rencana perbaikan pada siklus I yang dilaksanakan sebanyak 3 kali pertemuan apabila pada siklus I peningkatan anak minimal sebanyak $60 \%$ belum terpenuhi maka dilanjutkan pada siklus ke II dengan 3 kali pertemuan minimum mencapai target $60 \%$, apabila pada siklus II peningkatan kemampuan terpenuhi maka penelitian dinyatakan selesai.

Pelaksanan tindakan kelas ini dilakukan perencanaan, observasi dan refleksi dengan alur pelaksanaan tindakan seperti gambar 1 .

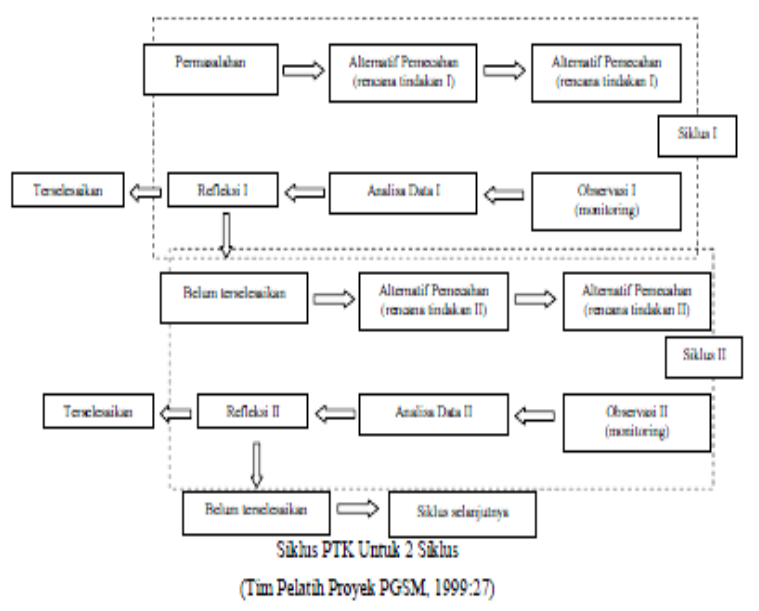

Gambar 1.

Alur Pelaksanaan Tindakan

\section{HASIL PENELITIAN DAN PEMBAHASAN}

\footnotetext{
Pendidikanusiadini merupakanmedia pendidikan yang sangatmendasardanutamadalammemberikanpener apandasarterbentuknyasikapdanketerampilanpada anak. Keberhasilanpadajenjang PAUD menjadiujungtombakuntukmelanjutkan proses pendidikankejenjangtingkatselanjutnya.
}

KesuksesanpelaksanaanpendidikanPAUD, seperti :KelompokBermain, Taman PenitipanAnak, Satuan PAUD sejenis maupun Taman Kanakkanaksangattergantungpadasistemdan proses pendidikan yang dijalankan.

Menyanyiadalahsuatuhal yang takterpisahkandaridunianak anak.Menyenandungkanlaguataunyanyian, apalagi yang beriramariang, sungguhkegiatan yang merekagandrungi.Hal initidaklahmengherankan,

karenalaguataunyanyianpadadasarnyaadalahsuatu bentukdaribahasa nada (melodi), yaitubentukharmonidaritinggirendahnyasuara (Sukarsih, 2002:117).

Kegiatanbernyanyiadalahmerupakankegiata ndimanakitamengeluarkansuarasecaraberaturanda nberiramabaikdiiringiolehalatmusikataupuntanpai ringanmusik (Jamalus, 1975:46).Bernyanyi mempunyai peranan penting dalam perkembangan prakeaksaraan di Taman KanakKanak, terutama perkembangan bahasa, tujuan dalam kegiatan bernyanyi adalah untuk memupuk irama dan perasaan estetis, memperkaya pembendahaaran bahasa dan melatih daya ingat, dan bernyanyi memberi kepuasan, kegembiraan, dan kebahagiaan bagi anak sehingga bisa mendorong anak supaya lebih giat belajar. Kemampuan berbicara sebetulnya bisa dimulai dari lingkungan terkecil yaitu di rumah sebagai satuan pendidikan terkecil dimana anak mulai diajak berkomunikasi dan mengembangkankemampuanmengungkapkan kata - kata dengan baik dan benar, orang tua sebagai pendidik di lingkungan rumah sebaiknya membantu perkembangan berbicara anak tersebut, untuk lebih menambah motivasi dan semangat anak dalam kemampuan berbicara anak.

\section{Fauziddin} mengemukakanbahwakemampuananakbernyanyi secaraumumdapatdibagikedalambeberapakelomp okdibawahini:

1. Mereka yang dapatbernyanyitanpabantuan. Anak yang termasukgolonganiniadalahanak anak yang dapatmenyanyikan nada 


\section{JURNAL CERIA}

ISSN : 2614-6347 (Print) 2614-4107 (Online)

Vol.1 No.2 | Maret 2018

dengantepatdantetap, sertamaudanmampubernyanyisendiri.

2. Mereka yang dapatbernyanyidenganbantuan. Anak - anakiniadalahmereka yang belajarbernyanyisecepatanakmacampertama yang telahdisebutkan, jikabernyanyibersama - sama.

3. Mereka

yang memulaiataumengakhirilagutidaktepat.

Merekadapatbernyanyidengantinggi nada yang benartetapipadasaat yang salah.

4. Mereka yang bernyanyipadaoktaf yang salah. Merekacenderungmenyanyikanmelodidengan nada satuoktaflebihrendahdaritinggi nada yang telahditentukan.

5 .

Mereka

yang bernyanyikurangtepatdenganoktaf yang salah. Anak

anakdalamkelompokinimenghadapiduamasalah:

pertama,

merekamemulaiataumengakhirilagutidakpadawak

tunya; kedua,

merekacenderungmenggunakansuararendah.

Dalamhalini penelitian dilakukan pada Kelompok B2usia 5-6 Tahun yang berjumlah 16 orang anak yang terdiri dari 11 orang laki-laki dan 5 orang perempuan. Melalui metoda bernyanyi anak akan dengan cepat mencerna dan mengulang kata yang disampaikan oleh guru, sehingga anak dapat meningkatkan kemampuan prakeaksaraan dan mengungkapkan bahasa dengan bernyanyi.

Kegiatan diawali dengan melihat kondisi anak dalam kemampuan prakeaksaraan melalui penelitian prasiklus, dari penelitian pra siklus didapatkan hasil Dari tabel di ataskemampuanprakeaksaraananaksebelumdilaku kantindakandapatdiketahuianakpadabelumberkem bangsebanyak $87,50 \%$, anakdidik yang mulaiberkembang $\quad 12.50 \quad \%$, sertabelumadanilaiperkembangansesuaiharapanda nberkembangsangatbaik.

Masihdidapatkanhasilrendahnyakemampuanprake aksaraananakdarihasilobservasimasihditemukank urangnyakemampuanpengenalanbahasa yang baik, perilakuanak yang pemalusehinggatidakdapatdapatmenyanyidanberb icaradenganbaikdengantemansebayanya, selainitukurangnyametode yang digunakan guru untukmerangsangkemampunberbicaraanak di dalamkelas terlihat pada grafik 1 .

Grafik 1. Penilaian Prasiklus Kemampuan Prakeaksaraan Anak Melalui
Metode Bernyanyi

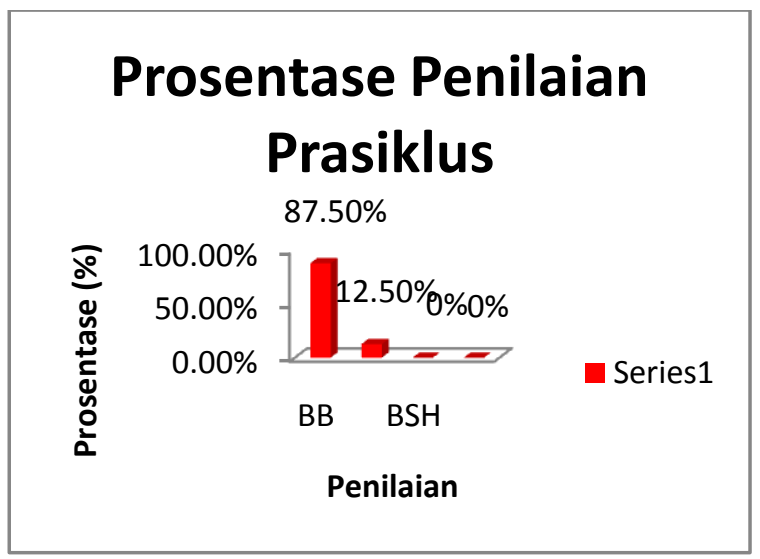

Penelitian dilanjutkan dengan pelaksanaan tindakan pada siklus I didapatkan hasil 11 anak masih belum berkembang atau diprosentasikan sebesar 68,75\%, 5 anak sudah mulai berkembang atau sebesar $31,25 \%$, belum ada peningkatan anak sesuai dengan harapan dan berkembang sangat baik

Grafik 2.

Penilaian Siklus I

Kemampuan PraKeaksraan Anak Melalui Metode Bernyanyi

\section{Penilaian Siklus I}

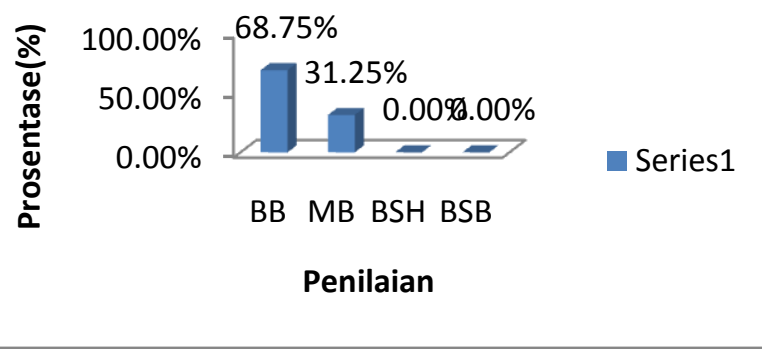

Penelitian pada siklus I masih didapatkan masih ada anak yang masih bermain dalam 


\section{JURNAL CERIA}

ISSN : 2614-6347 (Print) 2614-4107 (Online)

Vol.1 1 No.2 1 Maret 2018

kegiatan bernyanyi dan asik dengan kesibukannya, anak belum fokus dalam proses pembelajaran, ada yang berlari-larian kesana kemari, dengan demikian dilakukan perbaikan perencanaan di siklus II dengan perencanaan yang lebih baik, Setelah perencanaan dibuat dengan koordinasi dengan guru, maka dilaksanaan tindakan pada siklus II dengan 3 kali pertemuam, melihat hasil yang didapatkan dan analisa lapangan didapatkan peningkatan kemampuan prakeaksaraan anak 2 anak belum berkembang terjadi penurunan dari siklus I sebesar $68.75 \%$ menjadi $12,50 \%, 9$ anak sudah mulai berkembang dari $31,25 \%$ terjadi peningkatan menjadi $56,25 \%$ atau meningkat $25 \%, 5$ anak sudah berkembang sesuai harapan terjadi peningkatan dari kondisi awal $0 \%$ menjadi $31,25 \%$ terjadi peningkatan sebesar $31,25 \%$

Pelaksanaan pada siklus II melalui perbaikan perencanaan dirancang sedemikian rupa bertolak dari kelemahan dan keterbatasan waktu tersebut sehingga peneliti berkordinasi dengan guru kelas untuk meminimalisasi kelemahan-kelemahan yang menjadi kendala di siklus I

\section{Grafik 3.}

Penilaian Siklus II

Kemampuan PraKeaksaraan Anak Melalui Metode Bernyanyi

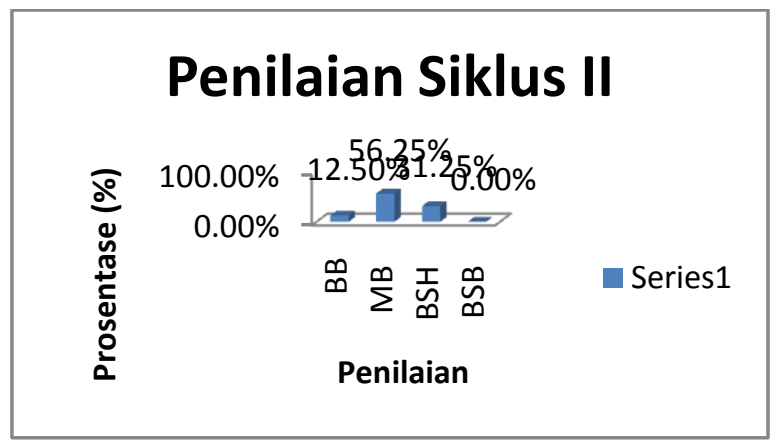

Penelitian mulai dari prasiklus, siklus I dan siklus II terjadi peningkatan dalam kemampuan prakeaksaraan anak melalui metode bernyanyi, rekapitulasi penilaian dari prasiklus, siklus I dan siklus II terlihat di Tabel 1
Tabel 1.

\section{Penilaian Rekapitulasi Nilai Kemampuan PraKeaksaraan Anak Melalui Metode Bernyanyi}

\begin{tabular}{|l|c|c|c|}
\hline \multicolumn{1}{|c|}{ Kategori } & prasiklus & siklus I & $\begin{array}{c}\text { siklus } \\
\text { II }\end{array}$ \\
\hline BB & $87,50 \%$ & $68,75 \%$ & $12,50 \%$ \\
MB & $12,50 \%$ & $31,25 \%$ & $56,25 \%$ \\
BSH & $0,00 \%$ & $0,00 \%$ & $31,25 \%$ \\
BSB & $0,00 \%$ & $0,00 \%$ & $0,00 \%$ \\
\hline
\end{tabular}

Dari tabel diatas didapatkan peningkatan kemampun prakeaksaraan anak melalui metode bernyanyi dari prasiklus prosentase anak belum berkembang menurun dari $87,50 \%$ menjadi $12,50 \%$, anak yang mulai berkembang meningkat dari $12,50 \%$ menjadi $56,25 \%$, anak yang berkembang sesuai harapan meninkjat menjadi $31,25 \%$ dari $0 \%$.

Grafik 4.

\section{Penilaian Rekapitulasi Nilai Kemampuan PraKeaksaraan Anak Melalui Metode Bernyanyi}

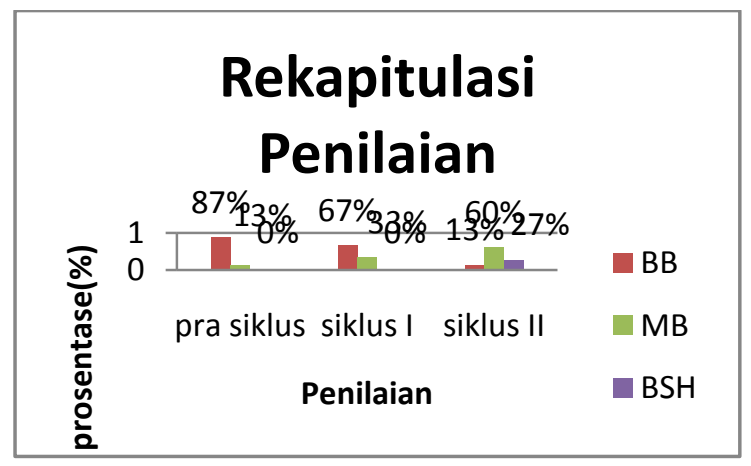

Berdasarkan grafik 4. terlihat penelitian pada pra siklus, siklus I dan siklus II terjadi peningkatan pada kemampuan prakeaksaraan anak melalui metode bernyanyi 


\section{JURNAL CERIA}

ISSN : 2614-6347 (Print) 2614-4107 (Online)

Vol.1」No.2」Maret 2018

penelitian tahap awal dilakukan melalui siklus 1. Pada penelitian pra siklus diperoleh nilai dengan hasil 10 orang anak belum berkembang dan 5 orang anak mulai berkembang, karena hasilnya belum memenuhi kriteria penilian dilanjutkan ke siklus II untuk memperbaiki perencanaan di siklus I, dari penelitian siklus ke II didapatkan hasil yang signifikan 2 orang anak belum berkembang jika diprosesntasekan diperoleh nilai sebesar $12,50 \%, 9$ orang anak sudah mulai berkembang jika diprosentasekan diperoleh nilai sebesar $59,25 \%$ dan 5 orang anak sudah berkembang sesuai harapan atau jika diprosentasekan diperoleh nilai sebesar $31,25 \%$, Dari prosentase tersebut diakumulasikan terjadi peningkatan rata rata sebesar $67,26 \%$.

\section{SIMPULAN}

Berdasarkan hasil penelitian tindakan kelas yang telah dilakukan, dan setiap siklusnya dilakukan langkah-langkah perencanaan, pelaksanaan, pengamatan, dan refleksi. Disimpulkan bahwa penggunaan metode bernyanyi dapat digunakan untuk meningkatkan kemampuan prakeaksaraan anak usia dini, penelitian ini ditunjukan dengan adanya peningkatan kemampuan prakeaksaraan anak usia dini sebesar $67 \%$, dengan demikian saran yang disampaikan kepada pendidik untuk lebih memahami dan mencari stimulus-stimulus utuk dapat meningkatkan kemampuan prakeaksaraan untuk anak usia dini, sehingga anak menjadi semangat untuk mengikuti pembelajaran di kelas dan memotivasi anak untuk mengungkapkan bahasa dalam kesehariannya selain itu bagi peneliti yang sejenis yang dilakukan bisa dijadikan referensi bahwa melalui metode bernyanyi dapat meningkatkat kemampuan prakeaksaraan anak usia dini.

\section{DAFTAR PUSTAKA}

Fauziddin, Mohammad. (2017). Pembelajaran $P A U D$ Bermain,
CeritadanMenyanyiSecaralslami. Bandung: PT. RemajaRosdakarya

Jamalus.

1988

PanduanPengajaranBukuPengajaranMusik

MelaluiPengalamanMusik. Jakarta:

ProyekpengembanganLembagaPendidikan.

Masitoh, dkk (2005).PendekatanBelajarAktif di

Taman Kanak - kanak.Jakarta: Depdiknas

Santoso, S. (2007).Dasar-DasarPendidikan TK. Jakarta: Universitas Terbuka.

Sukarsih, KartiHari. (2002). Media PembelajarandanJenis-jenis Media

Pembelajaran. Jakarta: PT.

RajaGrafindoPersada 